\title{
A Research Oriented To Determine the Perspectives of Car Rental Establishment Managers towards Handicapped Market
}

\author{
Doğan Kutukiz ${ }^{1}$, Bayram Akay², Abdullah Uslu ${ }^{3}$ \\ ${ }^{1}$ Mugla Sitkı Koçman University \\ ${ }^{2}$ Kirklareli University, \\ ${ }^{3}$ Mugla Sitkı Koçman University
}

\begin{abstract}
The researches regarding the handicapped revealed that 10\% of the world and $12.9 \%$ of our country's population experience a type of handicap. Procuring the participation of handicapped citizens, who form an important portion of the market, to the tourism activities will both help develop the tourism and provide for the needs of handicapped citizens such as trips, holidays, shopping and recreation just like other people. The aim of this research is to determine the perspectives of car rental establishment managers towards handicapped market. 67 managers were given the questionnaire within the scope of the research. As a result, it was determined that only $37 \%$ of the establishment served the handicapped citizens at least once. It can be stated that, in general, the establishments care about the handicapped market but they are insufficient about the investments required.
\end{abstract}

Keywords: Handicapped Market, Tourism, Car Rental.

JEL Classification: Z32, M12, M31

\section{Introduction}

"According to United Nations data, around 650 million handicapped citizens live in the world. This number, along with the families, reach to 2 billion people, which corresponds to $1 / 3$ of the world population (European Communities, 2004, p. 5). There are around 46 million physically or mentally handicapped citizens living only in Europe. Considering the pregnant women who have movement difficulties and the population above 65 , this number increases to 130 million people. This biggest minority of the world means a "special market" for tourism industry as well (TÜRSAB, 2008).

The comprehensive regulation oriented to the handicapped citizens in our country, where 8,5 million handicapped that form 12,29\% of the total population, is the Law No. 5378 made in 2005. According to this provision, all the official buildings, roads, pavements, pedestrian crossings, open and green areas, sports areas and similar social and cultural infrastructure areas belonging to public institutions and organizations and all types of constructions made by real and legal entities serving open to public must be constructed to allow handicapped accessibility (Law on Handicapped Citizens, 2005).

The car rental establishments, which fall into tourism and passenger transportation, constitute a portion of total transportation sector (Raskop, 1994:49). Vehicle renting, car rental or automobile rental is the renting of vehicles such as automobile, truck, pickup, motorbike and bicycle in exchange of a specified period of time (hourly, weekly, monthly or annually), which is based on a contract between the parties (Maximiliano, 2011, p. 275; Cho and Rust, 2010, p. 561). Car rental establishments also provide additional products and services such as child seat, navigation device, HGS for bridge and highway passages, Bluetooth car kit, fuel, snow chain, snow tire, additional driver, one-way rental, rental with chauffeur, delivery to the address and receiving from the address.

Along with the fact that effective regulations for handicapped citizens that have been neglected for years have been enforced in many countries (especially in developed countries) and that these regulations have slowly begun to take effect, the handicapped citizens, who have become more mobile compared to past and obtained social opportunities, started to travel more (TÜRSAB, 2008). In this study, the aim is to determine the perspectives of car rental establishment managers towards handicapped market.

\section{Literature Review}

United Nations General Assembly defines the handicapped citizens as, "Those who are not able to carry out the works which a normal person is supposed to do by himself/herself in his/her personal or social life due to a genetic or non-inherited deficiency in their physical or mental capabilities" (Koca, 2010 p. 3). Depending on different reasons, the handicapped people are examined in 5 categories, being: physicallyhandicapped (movement limitation due to loss of organs such as hand or feet or organ paralysis), visuallyhandicapped (blindness, low vision), aurally-handicapped (deafness, low hearing), speech-handicapped (speech and tongue disorders) and mentally-handicapped (David and Kiss, 2011). 
A series of regulations and incentives were made in Turkey oriented to aid the handicapped citizens for traveling. Private and public mass transportation systems and private and public mass transportation vehicles with nine or more seats other than driver's seat are obliged to be in conformity for handicapped accessibility (Law on Handicapped Citizens, 2005).Motorcycles (including mopeds) and wheeled vehicles with an auxiliary engine, which have been equipped with special installments that allow the disabled and handicapped citizens with $40 \%$ or more disability easier personal usage, have been exempted from the first ÖTV (Special Consumption Tax), once in five years (Gençyürek, 2011).In addition, the salary for handicapped provided for individuals with $40 \%$ or more disability rate (Kılıç, 2010) and their families, salary for handicapped citizens in need for care and salary for the relatives of the handicapped are the most important and consistent economical supports (Camkurt, 2013).

"The obstacle of accessibility in tourism sector is more important for handicapped citizens. Since they cannot access tourism facilities and services, they cannot benefit from those services. Another obstacle is the attitude of employees towards the handicapped citizens. The negative attitude of the personnel towards a handicapped citizen also affects his satisfaction. This important market cannot be benefited from unless the access is provided for handicapped citizens to tourism services and the personnel employed in tourism establishments have a positive attitude" (Card, 2003, p. 3).

A research in Poland revealed that $60 \%$ of handicapped citizens preferred their private vehicles and most of the non-handicapped (65\%) senior citizens preferred the tour buses (Jaremen, 2013). According to another research made in Australia, most of the handicapped citizens prefer their private vehicles that is more costly instead of mass transportation systems and few of them normal and specially-equipped rented vehicles [(See Table 1) (The Sustainable Tourism Cooperative Research Centre, 2008)].

Table 1: Destination Reaching Type for the Handicapped in Australia

\begin{tabular}{|l|l|l|l|}
\hline Destination Reaching Type & All $(\mathbf{\%})$ & Wheelchair $(\mathbf{\%})$ & Other $(\mathbf{\%})$ \\
\hline Private Cars & 59.8 & 54.0 & 67.3 \\
\hline Airplane & 15.9 & 16.8 & 14.2 \\
\hline Fitting Special Cars & 11.0 & 17.6 & 3.1 \\
\hline Train & 5.1 & 3.4 & 7.5 \\
\hline Bus/Minibus & 3.7 & 2.5 & 5.9 \\
\hline Car Rental & 0.6 & 0.6 & 0.6 \\
\hline Fitting Special Car Rental & 0.1 & 0.2 & 0.1 \\
\hline
\end{tabular}

Source: SustainableTourismCooperativeResearchCentre, 2008:6.

When the web sites of some international car rental establishments (Avis, Budget, Hertz, Alamo, and CaroVermietung) are observed, it is seen that they provide car-rental services for handicapped within their range of products. In addition, additional products such as hearing device for aurally handicapped, pedal extension kit, wheelchair and rental services with private chauffeurs are provided as well. Apart from that, there are car rental companies oriented to handicapped citizens in Europe and USA (disability car hire, adapted vehicle hire, etc.). Car Rental Company Avis provides the following services in its operations oriented to handicapped market (Narsing, Sanders ve Ford, 2013, p. 93):

- Scooter Rental: Rental of gearless motors that the handicapped citizens can also use and that can be delivered at/taken from the current address.

- Transfer Board: Enables easier transfer from a wheelchair into and out of the vehicle.

- Panoramic Mirror: Provides a much larger field of view for any driver.

- Rotating Seat: Allows the driver or passenger to turn his or her body in the car seat with limited effort.

- Hand Controls: Enables drivers to accelerate or brake using a hand-controlled device.

- Spinner Knob: Enables the driver to turn the steering wheel with a full turning radius using only one hand.

- Powered handicapped ramp: It allows the handicapped individual to get in the car easily with the wheelchair. In addition, vehicles with large doors and aisles and low baggage rack are among the conveniences for handicapped citizens.

\subsection{The Objective and Importance of the Research}

It is known that the regulations oriented to the handicapped citizens are insufficient in developing countries like Turkey compared to developed countries. This study that takes this fact as basis aims to determine the perspectives of car rental establishment managers towards handicapped market.

As a result of the literature scanning, it was observed that there were some studies, although few in numbers, on handicapped market (Card, 2002; Arıc1, 2010; Eryılmaz, 2010; Yürik and Avc1, 2008; Çizel, Buhalis and Darcy, 2012, Sönmez and Akınc1, 2012) accommodation establishments (Yaylı and Öztürk, 2006), and tour operators/travel agencies (Patterson et al., 2012; Öztürk and Yayl1, 2006). Related to the subject, there 
are not any studies on car rental establishments among the studies in international and national literature. In this sense, this study is important in terms of contributing the literature on related area and developing solutions oriented to handicapped market.

\subsection{The Population, Sample and Method of the Research}

The managers of the car rental establishments in Mugla, which ranks 3rd in terms of most touristpopulated city in Turkey, constitute the population of this research. Within this population, the managers of the car rental establishments in Fethiye and Dalaman counties, two of the important tourism centers in Mugla province, were preferred as samples. Since it is difficult in terms of labor, time and cost to reach the universe in the research, simple random sampling method was used in the research as sample.

Questionnaire method, one of the questionnaire research methods, was used in the research. The questionnaire was made in Fethiye and Dalaman between June 19 - August 14, 2014. This questionnaire was conducted by face-to-face meeting with the managers. The number of directors interviewed is 75 . After the investigation, questionnaire of 67 directors were taken for evaluation and 8 questionnaires were excluded due to important deficiencies. There are not any final data on the number of car rental establishments in Turkey. According to Turkish Hoteliers Federation (2012, p. 19), along with 7 international brands, there are more than 30 companies and 650 local corporations in operation in Turkey in car rental market.

\subsection{Limitations of the Research}

This study was conducted in a limited area (Mugla Province) with limited participants (managers of 67 car rental establishments in Fethiye and Dalaman touristic city). Arguing that the results can represent the general may not be an objective approach. However, it is considered that the study can make contributions to the literature as one of the limited researches made in the specified area. The results of this study may be compared in the new researches to be made by means of reaching more participants.

\subsection{Data Analysis and Reliability}

The results obtained from the questionnaires were used to create a database by means of using SPSS (Statistical Program for Social Science) 22.00 for Windows package software. The percentage, arithmetic means and standard deviation values of the research data were calculated. The scales whose validity and reliability were proved was used in the research. The scales adapted from hotel establishments to car rental establishment (the perspective of managers towards the handicapped market and things required to be done for handicapped market (Yaylı and Öztürk, 2006)) were used; the suitability of the establishments for handicapped markets is also addressed in the literature by Narsing, Sanders and Ford (2013). In addition, personal data was formed by the researchers and the questionnaire was finalized after being examined by 2 academics having expertise on statistics and tourism.

\section{Results}

51 of the car rental establishment managers participated in the questionnaire $(76,1 \%)$ were male and 16 of them $(23,9 \%)$ were female. In this case, it is understood that men are employed more in this sector. In addition, the fact that most of the managers $(58,7 \%)$ are married indicates that the revenue obtained from the sector is sufficient for family living. Considering the education status, it is observed that the education level of the managers is high (41,8\% higher education and 37,3\% secondary education). Most of the car rental establishments $(59,7 \%)$ employs $1-10$ people and many of those $(79,1 \%)$ operate for more than a year. $41,3 \%$ of the respondents are senior managers and the remaining 55,7\% are middle level managers.

Table 2. Sample of Research Findings

\begin{tabular}{|l|l|l|l|l|l|}
\hline Gender & Freguency & Percentage (\%) & Marital Status & Freguency & Percentage (\%) \\
\hline Male & 51 & 76,1 & Married & 39 & 58,7 \\
\hline Female & 16 & 23,9 & Single & 28 & 41,3 \\
\hline Total & 67 & 100,0 & Total & 67 & 100,0 \\
\hline Educational Status & & Number of Employees & & \\
\hline Primary School (8 years) & 14 & 20,9 & $1-10$ People & 40 & 59,7 \\
\hline $\begin{array}{l}\text { Secondary Education (High } \\
\text { School) }\end{array}$ & 25 & 37,3 & $11-20$ People & 21 & 31,3 \\
\hline Higher Education & 29 & 41,8 & 21 and above & 6 & 9,0 \\
\hline Total & $\mathbf{6 7}$ & $\mathbf{1 0 0 , 0}$ & Total & $\mathbf{6 7}$ & $\mathbf{1 0 0 , 0}$ \\
\hline Duty in the Establishment & & & Activity Period & & \\
\hline Senior Manager & 28 & 41,3 & Less than 1 year & 14 & 39 \\
\hline Mid-Level Manager & 39 & 55,7 & $1-10$ years & 39,9 & 58,2 \\
\hline Total & $\mathbf{6 7}$ & $\mathbf{1 0 0 , 0}$ & 11 and above & 14 \\
\hline
\end{tabular}


According to Table 3, 37,3\% of the car rental establishments serve handicapped citizens while $62,7 \%$ of them have not served them yet. This indicates that the level of car rental establishments serving to handicapped customers is low.

Table 3. The Status of Establishments on Serving Handicapped Customers

\begin{tabular}{|l|l|l|}
\hline Serving Status & Frequency & Percentage (\%) \\
\hline Yes & 25 & 37,3 \\
\hline No & 42 & 62,7 \\
\hline Total & 67 & 100,0 \\
\hline
\end{tabular}

The agreement levels of the managers to the opinion were indicated with the interpretation of the mean (X) values of the questionnaire as follows: $X=1-1,79$ none, $X=1,80-2,59$ moderate, $X=3,4-4,19$ high and $X=4,2$ 5 very high (Yaylı and Öztürk, 2006).

The results indicating the perspectives of car rental establishment managers towards handicapped market are summarized in Table 4. In the first question of the managers were asked with their opinions regarding the duties of non-governmental organization and associations on the handicapped citizens participating in the tourism and they supported the opinion that related organizations did not work actively in this area. This result indicates consistency with the findings of the research by Yaylı and Öztürk (2006, p. 92).

The 2nd and 3rd questions were asked in order to test whether the vehicles are suitable for physicallyhandicapped customers. More than half of the managers participating the questionnaire agreed that the vehicles are not suitable for physically-handicapped $(X=4,13)$ and that special automobiles should be manufactured $(X=4,12)$. In this sense, the automatic cars can be driven by the physically-handicapped in the establishments. In addition, with special equipment and hardware, the vehicles can be made suitable for handicapped citizens' usage.

The managers stated that the current transportation infrastructure $(X=3,76)$ and environmental arrangement $(X=3,98)$ is not suitable for handicapped citizens. This study is consistent with the result obtained from the previous studies (Yaylı and Öztürk, 2006, p. 14, Atıc1, 2008, p. 41-43, Arıc1, 2010, p. 75) that the environmental arrangements oriented to handicapped citizens are not suitable.

The training of the personnel is very important in serving physically-handicapped. Related to this, more than half of the managers stated that they agreed with the opinion that the employees do not possess the sufficient level of information in serving physically handicapped $(X=3,84)$. This clearly indicates the employees' lack of information about the issue.

According to the last 2 questions formed with the purpose of putting forth the physically-handicapped market structure, an important portion of the managers agree with the fact that the managers are not aware of the physically-handicapped market $(X=3,63)$ and that it does not make enough money $(X=3,64)$. These results indicate consistency with the results of the research made by Eryllmaz (2010, p. 293).

Table 4. The Opinions of Managers on Handicapped Market

\begin{tabular}{|c|c|c|c|c|c|c|c|}
\hline \multirow[t]{2}{*}{ STATEMENTS } & \multicolumn{5}{|c|}{$\begin{array}{l}\text { 1:Strong Disagree; } \\
\text { 5:Strong Agree }\end{array}$} & \multirow{2}{*}{$\stackrel{\Xi}{\stackrel{\Xi}{\Sigma}}$} & \multirow{2}{*}{ : } \\
\hline & 1 & 2 & 3 & 4 & 5 & & \\
\hline $\begin{array}{l}\text { The associations in this area do not work } \\
\text { actively }\end{array}$ & $\begin{array}{l}0 \\
(0,00)\end{array}$ & $\begin{array}{l}0 \\
(0,00)\end{array}$ & $\begin{array}{l}15 \\
(22,4)\end{array}$ & $\begin{array}{l}28 \\
(41,8)\end{array}$ & $\begin{array}{l}24 \\
(35,8)\end{array}$ & 4,14 & ,756 \\
\hline $\begin{array}{l}\text { The current structures of the automobiles are } \\
\text { not suitable for physically-handicapped }\end{array}$ & $\begin{array}{l}1 \\
(1,5)\end{array}$ & $\begin{array}{l}2 \\
(3,0)\end{array}$ & $\begin{array}{l}7 \\
(10,5)\end{array}$ & $\begin{array}{l}34 \\
(50,7)\end{array}$ & $\begin{array}{l}23 \\
(34,3)\end{array}$ & 4,13 & ,837 \\
\hline $\begin{array}{l}\text { Specially-designed automobiles should be } \\
\text { produced for physically-handicapped }\end{array}$ & $\begin{array}{l}1 \\
(1,5)\end{array}$ & $\begin{array}{l}12 \\
(17,9)\end{array}$ & $\begin{array}{l}0 \\
(0,00)\end{array}$ & $\begin{array}{l}31 \\
(46,3)\end{array}$ & $\begin{array}{l}23 \\
(34,3)\end{array}$ & 4,12 & ,807 \\
\hline $\begin{array}{l}\text { Environmental arrangements are not suitable } \\
\text { for physically-handicapped }\end{array}$ & $\begin{array}{l}1 \\
(1,5)\end{array}$ & $\begin{array}{l}5 \\
(7,5)\end{array}$ & $\begin{array}{l}12 \\
(17,9)\end{array}$ & $\begin{array}{l}25 \\
(37,3)\end{array}$ & $\begin{array}{l}24 \\
(35,8)\end{array}$ & 3,98 & ,992 \\
\hline $\begin{array}{l}\text { The level of personnel working in car rental } \\
\text { establishment in serving handicapped } \\
\text { citizens is low }\end{array}$ & $\begin{array}{l}3 \\
(4,5)\end{array}$ & $\begin{array}{l}3 \\
(4,5)\end{array}$ & $\begin{array}{l}15 \\
(22,4)\end{array}$ & $\begin{array}{l}27 \\
(40,3)\end{array}$ & $\begin{array}{l}19 \\
(28,4)\end{array}$ & 3,84 & $\begin{array}{l}1,03 \\
8\end{array}$ \\
\hline $\begin{array}{l}\text { Transportation infrastructure is not suitable } \\
\text { for physically-handicapped }\end{array}$ & $\begin{array}{l}3 \\
(4,5)\end{array}$ & $\begin{array}{l}8 \\
(11,9)\end{array}$ & $\begin{array}{l}11 \\
(16,4)\end{array}$ & $\begin{array}{l}25 \\
(37,3)\end{array}$ & $\begin{array}{l}20 \\
(29,9)\end{array}$ & 3,76 & $\begin{array}{l}1,14 \\
2\end{array}$ \\
\hline $\begin{array}{l}\text { Handicapped market does not make enough } \\
\text { money }\end{array}$ & $\begin{array}{l}1 \\
(1,5)\end{array}$ & $\begin{array}{l}6 \\
(9,9)\end{array}$ & $\begin{array}{l}22 \\
(32,8)\end{array}$ & $\begin{array}{l}25 \\
(37,3)\end{array}$ & $\begin{array}{l}13 \\
(19,4)\end{array}$ & 3,64 & ,948 \\
\hline $\begin{array}{l}\text { The managers are not aware of handicapped } \\
\text { market }\end{array}$ & $\begin{array}{l}1 \\
(1,5)\end{array}$ & $\begin{array}{l}7 \\
(10,4)\end{array}$ & $\begin{array}{l}22 \\
(32,8)\end{array}$ & $\begin{array}{l}23 \\
34,3)\end{array}$ & $\begin{array}{l}14 \\
(20,9)\end{array}$ & 3,63 & ,982 \\
\hline Cronbach's Alfa $=, 80$ & & & & & & & \\
\hline
\end{tabular}

The suitability of car rental establishment for handicapped customers is stated in Table 5. In that, the most suitable rent-a-car establishments for the handicapped citizens are those having well-suited entrances, parking areas, vehicles with large doors and aisles (vehicles having the capacity to carry 8 or more people). It is observed that the hardware and units that require extra cost such as panoramic mirror, transfer board, 
handicapped vehicle, spinner knob, powered handicapped ramp, rotating seat and hand controls are not sufficient. As it can be observed, the investments on the handicapped market for units that do not fall within the legal responsibility (establishment entrance, park areas) are not sufficient.

Table 5. The Suitability Status of Establishments for Handicapped Customers

\begin{tabular}{|l|l|l|l|l|l|l|l|}
\hline $\begin{array}{l}\text { Opportunities Offered by } \\
\text { the Establishment }\end{array}$ & $\begin{array}{l}\text { Available } \\
\text { (f) }\end{array}$ & $\begin{array}{l}\text { Percentage } \\
(\%)\end{array}$ & $\begin{array}{l}\text { Not Available } \\
\text { (f) }\end{array}$ & $\begin{array}{l}\text { Percentage } \\
(\%)\end{array}$ & $\begin{array}{l}\text { No Service } \\
(\mathbf{f})\end{array}$ & $\begin{array}{l}\text { Percentage } \\
(\%)\end{array}$ & n \\
\hline Park Areas & 33 & 49,3 & 14 & 20,9 & 20 & 29,9 & 67 \\
\hline Establishment Entrance & 29 & 43,3 & 17 & 25,4 & 21 & 31,3 \\
\hline $\begin{array}{l}\text { Large Door and Aisled } \\
\text { Vehicle }\end{array}$ & 30 & 40,3 & 10 & 14,9 & 27 & 44,8 \\
\hline Panoramic Mirror & 9 & 13,4 & 15 & 22,4 & 43 & 64,2 \\
\hline Transfer Board & 6 & 9,0 & 15 & 22,4 & 46 & 68,7 \\
\hline $\begin{array}{l}\text { Handicapped Vehicles } \\
\text { (automobile) }\end{array}$ & 5 & 7.5 & 16 & 23,9 & 46 & 68,7 \\
\hline Spinner Knob & 4 & 6,0 & 12 & 17,9 & 51 & 76,1 \\
\hline $\begin{array}{l}\text { Powered Handicapped } \\
\text { Ramp }\end{array}$ & 4 & 6,0 & 10 & 14,9 & 53 & 79,1 \\
\hline $\begin{array}{l}\text { Rotating Driver/Passenger } \\
\text { Seat }\end{array}$ & 3 & 4,5 & 14 & 20,9 & 50 & 74,6 \\
\hline Hand Controls & 3 & 4,5 & 15 & 22,4 & 49 & 73,1 \\
\hline
\end{tabular}

Table 6 below reflects the ideas of car rental establishments on the things required for the handicapped tourists shift to car rental market. The managers very strongly agree with the fact that cooperation should be made between Ministry of Culture and Tourism and non-governmental organizations (NGO) $(\mathrm{X}=4,29)$ and promotion activities should be emphasized $(X=4,28)$. In addition, they also strongly agree with the requirement for regulations $(X=4,18)$, the personnel receiving special training $(X=4,12)$, the government to take incentive precautions for the traveling of handicapped citizens $(X=4,00)$, the insufficiency of labels for handicapped citizens $(X=4,00)$ the necessity for car rental establishments only for handicapped citizens $(X=4,00)$ and the establishments lacking the sufficient documents for promotion $(X=3,88)$. Based on these results, it can be stated that the establishment expect the regulations required for handicapped market from their surroundings.

Table 6. Things Required for Handicapped Market

\begin{tabular}{|c|c|c|c|c|c|c|c|}
\hline \multirow[t]{2}{*}{ Statements } & \multicolumn{5}{|c|}{$\begin{array}{l}\text { 1:Strong Disagree; } \\
\text { 5:Strong Agree }\end{array}$} & \multirow{2}{*}{$\stackrel{\Xi}{\Xi}$} & \multirow{2}{*}{ के } \\
\hline & 1 & 2 & 3 & 4 & 5 & & \\
\hline $\begin{array}{l}\text { Ministry of Culture and Tourism and NGOs } \\
\text { should cooperate }\end{array}$ & $\begin{array}{l}0 \\
(0,00)\end{array}$ & $\begin{array}{l}0 \\
(0,00)\end{array}$ & $\begin{array}{l}6 \\
(9,0)\end{array}$ & $\begin{array}{l}36 \\
(53,7) \\
\end{array}$ & $\begin{array}{l}25 \\
(37,3)\end{array}$ & 4,29 & 622 \\
\hline Promotion activities should be emphasized & $\begin{array}{l}0 \\
(0,00)\end{array}$ & $\begin{array}{l}0 \\
(0,00)\end{array}$ & $\begin{array}{l}7 \\
(10,4)\end{array}$ & $\begin{array}{l}34 \\
(50,7)\end{array}$ & $\begin{array}{l}26 \\
(38,8)\end{array}$ & 4,28 & ,646 \\
\hline Regulations about this should be prioritized & $\begin{array}{l}0 \\
(0,00) \\
\end{array}$ & $\begin{array}{l}1 \\
(1,5) \\
\end{array}$ & $\begin{array}{l}8 \\
(11,9) \\
\end{array}$ & $\begin{array}{l}36 \\
(53,7) \\
\end{array}$ & $\begin{array}{l}22 \\
(32,8) \\
\end{array}$ & 4,18 & ,694 \\
\hline $\begin{array}{l}\text { Service personnel should be subjected to } \\
\text { special training }\end{array}$ & $\begin{array}{l}1 \\
(1,5) \\
\end{array}$ & $\begin{array}{l}1 \\
(1,5)\end{array}$ & $\begin{array}{l}8 \\
(11,9) \\
\end{array}$ & $\begin{array}{l}36 \\
(53,7) \\
\end{array}$ & $\begin{array}{l}21 \\
(31,3) \\
\end{array}$ & 4,12 & ,788 \\
\hline $\begin{array}{l}\text { The government should take incentive } \\
\text { precautions about physically-handicapped } \\
\text { participating in journeys }\end{array}$ & $\begin{array}{l}1 \\
(1,5)\end{array}$ & $\begin{array}{l}0 \\
(0,0)\end{array}$ & $\begin{array}{l}18 \\
(26,9) \\
\end{array}$ & $\begin{array}{l}27 \\
(40,3) \\
\end{array}$ & $\begin{array}{l}21 \\
(31,3) \\
\end{array}$ & 4,00 & 852 \\
\hline $\begin{array}{lcc}\text { The labels } & \text { oriented to physically- } \\
\text { handicapped } \\
\text { establishments }\end{array}$ & $\begin{array}{l}0 \\
(1,5)\end{array}$ & $\begin{array}{l}3 \\
(4,5)\end{array}$ & $\begin{array}{l}15 \\
(22,4)\end{array}$ & $\begin{array}{l}28 \\
(41,3) \\
\end{array}$ & $\begin{array}{l}21 \\
(31,3)\end{array}$ & 4,00 & ,852 \\
\hline $\begin{array}{l}\text { The establishments do not have sufficient } \\
\text { documents to introduce themselves to } \\
\text { physically-handicapped }\end{array}$ & $\begin{array}{l}1 \\
(1,5)\end{array}$ & $\begin{array}{l}3 \\
(4,5)\end{array}$ & $\begin{array}{l}16 \\
(23,9)\end{array}$ & $\begin{array}{l}30 \\
(44,8) \\
\end{array}$ & $\begin{array}{l}17 \\
(25,5)\end{array}$ & 3,88 & ,896 \\
\hline $\begin{array}{l}\text { There should be an individual establishment } \\
\text { to serve about this }\end{array}$ & $\begin{array}{l}1 \\
(4,5) \\
\end{array}$ & $\begin{array}{l}6 \\
(9,0) \\
\end{array}$ & $\begin{array}{l}13 \\
(19,4) \\
\end{array}$ & $\begin{array}{l}25 \\
(37,3) \\
\end{array}$ & $\begin{array}{l}20 \\
(29,9) \\
\end{array}$ & 3,79 & 1,108 \\
\hline $\begin{array}{l}\text { Since providing services to physically- } \\
\text { handicapped requires a high cost, it's a } \\
\text { negligible market segment }\end{array}$ & $\begin{array}{l}13 \\
(19,4)\end{array}$ & $\begin{array}{l}23 \\
(34,3)\end{array}$ & $\begin{array}{l}16 \\
(23,9)\end{array}$ & $\begin{array}{l}10 \\
(14,9)\end{array}$ & $\begin{array}{l}5 \\
(7,5)\end{array}$ & 2,56 & 1,183 \\
\hline Nothing is required to be done & $\begin{array}{l}25 \\
(37,3)\end{array}$ & $\begin{array}{l}26 \\
(38,8)\end{array}$ & $\begin{array}{l}12 \\
(17,9)\end{array}$ & $\begin{array}{l}3 \\
(4,5)\end{array}$ & $\begin{array}{l}1 \\
(1,5)\end{array}$ & 1,94 & ,935 \\
\hline Cronbach's Alfa $=, 66$ & & & & & & & \\
\hline
\end{tabular}

The managers do not really agree with the statement, "Since providing services to physicallyhandicapped requires a high cost, it's a negligible market segment" $(X=2,56)$. Almost all of those participating in the questionnaire stated that they did not agree with the statement, Nothing is required to be done" $(\mathrm{X}=1,94)$. These results indicate consistency with the findings of the research by Yaylı and Öztürk (2006, p. 93). 


\section{Conclusion And Suggestions}

The market of the handicapped, which form around $10 \%$ of the world population, is an important market that the tourism industry should consider. It was determined in the research that only $37 \%$ of the establishment served the handicapped citizens at least once. Regarding the handicapped market, the managers point out the insufficiency of the transportation infrastructure and environmental arrangements, the people unaware from the market and the market not making a lot of money, the vehicles not being suitable for handicapped and the necessity to produce automobiles for handicapped, the employees' lack of information on serving the handicapped citizens and the failure of related associations to work accordingly about this.

The most suitable car rental establishments for the handicapped citizens are those having well-suited entrances, parking areas, vehicles with large doors and aisles (vehicles having the capacity to carry 8 or more people). In addition, the units and equipment such as handicapped vehicles, transfer board, panoramic mirror, rotating seat, hand control device, spinner knob and powered handicapped ramp.

The managers do not agree the opinion 'Nothing is required to be done' for handicapped market (75\%) and that the 'Handicapped market is negligible' (65\%). In addition, the managers strongly agreed the fact that the state should take special precautions for the handicapped citizens; the insufficiency of the labels, the insufficiency in establishment promotion; that there should be a car rental establishment for handicapped citizens; personnel training, regulations, emphasizing on promotion and the need of cooperation between the Ministry of Culture and Tourism and non-governmental organizations. As a result, it was determined that the managers of the car rental establishments within the scope of the research care about the handicapped market and they are insufficient in making the necessary arrangements.

As Ray and Ryder (2003) emphasize, the handicapped market forms a big business market today. Therefore, the car rental establishments should immediately shift to this market by means of creating the necessary hardware infrastructure and training qualified personnel. Thanks to this market segment that can be moved with the coordination and contribution by both the government and the private sector (companies, nongovernmental organizations, associations etc.), the tourism revenues and employment ratio will increase.

Regulations such as the physical environment being made accessible for the handicapped citizens, public and private mass transportation vehicles being suitable for handicapped access, the government procuring rehabilitation services oriented to handicapped for blending in the society have been made in Turkey. Economical support include the salary for handicapped provided for individuals with $40 \%$ or more disability rate (Kılıç, 2010) and their families, salary for handicapped citizens in need for care and salary for the relatives of the handicapped are the most important and consistent economical supports. It can be made mandatory for car rental establishments that, just as in accommodation establishments (e.g. the hotels with a total room capacity of 80 and above and holiday camps having at least 1 room for handicapped), the establishments with 80 or more vehicles should at least have one vehicle for handicapped.

Car rental establishments can serve all the handicapped groups. Namely, automatic and speciallyequipped vehicles can be rented to handicapped groups (physically, aurally or speech-handicapped) which can obtain "H class" driver's license for handicapped. About other handicapped groups (visually and mentally handicapped), the establishment can market chauffeured car renting services. In addition, an establishment that will go in the market can completely shift to handicapped market as is in Europe and USA.

The fact that car rental establishments, which carries out the transportation function that is one of the important elements of tourism, shift to this market allows individual movement ability to handicapped citizens. In addition, there will be positive reflections to other tourism establishment as well (the increase in capacity of airline, entertainment, food-beverage, and accommodation).

For future researches to be conducted related to the subject, the activity can be extended to the extent that it will cover all the car rental establishments in Turkey. Along with car rental establishments, the perspectives of local administrations, non-governmental organizations and public institutions and organizations towards the handicapped market can be evaluated.

\section{References}

[1]. Arıcı, S. (2010). Bedensel engellilerin turizm sektöründen beklentilerinin tespit edilmesine yönelik bir araştırma (Yayınlanmamış yüksek lisans tezi), Gazi Üniversitesi, Ankara.(In Turkish)

[2]. Atıcı, E. (2001). Engelsiz yapılı çevre düzenlemelerinin mevzuat kapsamında incelenmesi, (Yayınlanmamış uzmanlık tezi), Özürlüler İdaresi Başkanlığı, Ankara.

[3]. Buhalis, D. \& Darcy, S. (2011). Accessibletourism: concepts and issues, UK: Channel View Publications.

[4]. Camkurt, Z. M. (2013). 2022 sayılı kanuna göre engelliliğin tespiti ve engelliliğe dayalı aylıkların bağlanması işlemleri, Mali Ç̈züm Dergisi, 119, 79-116.

[5]. Card, A. J. (2003). Aging and disabilit ypopulation trends: Their impact on tourism in the future, e-Review of Tourism Research (eRTR), 1(1), 1-4.

[6]. Cho, S. \& Rust, J. (2010). The flat rental puzzle, Review Of Economic Studies. 77, 560-594.

[7]. Ciochina, I. \& Iordache, M. C. (2012). The increase in the level of accessibility in touristic services through the promotion of social tourism offers:Study conducted in Valcea,Business \&Leadership, 2, 85-105. 
[8]. Çizel, B., Sönmez, N. \& Akıncı, Z. (2012). Antalya'da engelli turizminin gelişimi için arz ve talep üzerine bir araştırma. Ankara: Yiğitler Matbaa.

[9]. David,L. \& Kiss, N. (2011).Destination development and management for disabled people. Journal of Tourism Challenges\&Trends, 4 (2), 113-122.

[10]. Engelliler Hakkında Kanun, (2005). Kanun Numarası: 5378, Yayımlandı̆̆ı Düstur: Tertip: 5 Cilt: 44.

[11]. Eryılmaz, B. (2010). Turizmde engelli pazarının değerlendirilmesi ve bodrum örneği. Lisansüstü Tez Özetleri, Anatolia: Turizm Araştırmaları Dergisi, 21 (2), 289-297.

[12]. European Communities (2004). Improving information on accessible tourism for disabled, Luxembourg: Office for Official Publications of the European Communities, ISBN 92-894-7678-8.

[13]. Jaremen, E. D. (2013).The profile of the two main social tourism segments in Poland, Economics and Management,Ukrainian Food Journal, 3 (1), 86-95.

[14]. Koca, C. (2010). Engelsiz Şehirler Planlaması Bilgilendirme Raporu. İstanbul: Dünya Engelliler Vakfi Yayınları.

[15]. Maximiliano, K. (2011). Rent-a-car industry: a case study in Argentina tourismos: an international multidisciplinary. Journal of Tourism, 6 (1), 271-280.

[16]. Narsing, A.,Sanders, T. \& Ford, M. (2013). A model for managing rental fleets in the new competitive landscape: maintenance, productivity, corporate branding and legal implications, Academy of Information and Management Sciences Journal, 16.2, 85-102.

[17]. Patterson, L.,Darcy, S. \& Mönninghof, M. (2012). Attitudes and experiences of tourism operators in Northern Australia towards people with disabilities. World Leisure Journal, 54 (3), 215-229.

[18]. Raskop, R. R. (1994). Is the public being taken for a ride? the car rental industry: it'spolicies, practices, and the public interest, Doctoral Theses, California: Golden Gate University.

[19]. Ray, N. \& M. Ryder M. (2003) "Ebilities" tourism an exploratory discussion of the travel needs and motivations of the mobility disabled.Tourism Management, 24(1), 57-72.

[20]. Türkiye Otelciler Federasyonu (TÜROFED) (2012). Turizm Raporu, TÜROFED Dergisi, Sayı:5.

[21]. TÜRSAB [(Türkiye Seyahat Acenteleri Birliği) ( 2008)]. Dünyada ve Türkiye'de Engelsiz Turizm Pazarl, TÜRSAB Ar-Ge Departmanı Raporu.

[22]. Yaylı A. \& Öztürk, Y. (2006). Konaklama İşletmeleri Yöneticilerinin Bedensel Engelliler Pazarına Bakış Açıları Üzerine Bir Arastırma. Anatolia: Turizm Arastırmaları Dergisi, 17 (1), 87-97.

[23]. Yürik, E. \& Avcı N. (2008). Engelliler ve Turizm: Avrupa Birliği ve Türkiye Uygulamaları Üzerine Kavramsal Bir Karşılaştırma. Avrasya Etütleri, 34/2,109-125.

[24]. Adapted Vehicle Hire (2014). Adaptedcars, Wheel chair accessible vehicles, non-adapted cars, [http://www.adaptedvehiclehire.com], (Access 18 September2014).

[25]. Alamo Car Rental (2014). Customers with disabilities mobility devices, [https://www.alamo.com/en_US/car-rental/customers-withdisabilities.html], (Access 18 September2014).

[26]. Avis Car Rental (2014).Products and services, [http://www.avis.com/car-rental/content/display.ac?navId=T4M27S00], (Access 28August 2014).

[27]. Budget Car Rental (2014). Smart services, [http://www.budget.com/smartservices/ rentersWithDisabilities], (Access 28August 2014).

[28]. CaroVermietung (2013). Wirbieten den Mietwagen, [http://www.van-eupen.de/fileadmin/media/mietwagen/caro-flyer.pdf], (Access 12 February 2014)

[29]. Gençyürek, L (2011). Engellilere taşıt alımında sağlanan ÖTV indiriminde yeni gelişmeler, [http://www.alomaliye.com/2011/ levent_gencyurek_engellilere_tasit], [Access 15August 2014).

[30]. Disability Hire Vehicles (2014). Transport for the independent disabled traveller [http://www.disabilitycarhire.com.au],(Access 18 September2014).

[31]. Hertz Rent A Car (2014). Products and Services, [https://www.hertz.co.uk/rentacar/ productsandservices], (Access 28 August 2014).

[32]. Kılıç, R. (2010). Özürlü aylı̆̆l ve bakım parası almanın şartları, [http://www.engelliler.net/ozurlu-ayligi-ve-bakim-parasi-almaninsartlari], (Access 18August 2014).

[33]. Sustainable Tourism Cooperative Research Centre (2006). Accessible tourism: understanding an evolving aspect of australian tourism, [http://www.tourism.wa.gov.au], (Access 20 August 2014).

[34]. TUİK (Türkiye İstatistik Kurumu) (2002). Engelli istatistikleri, [http://www.tuik.gov.tr/UstMenu.do?metod], (Access 15 August 2014). 